\title{
The development of historical imagination on the example of an exercise addressed to first-year students of history at Nicolaus Copernicus University
}

\section{KEYWORDS}

an imagination, a teaching, an interdisciplinarity, field exercises, a history

\begin{abstract}
Laddach Agnieszka, The development of historical imagination on the example of an exercise addressed to firstyear students of history at Nicolaus Copernicus University. Culture - Society - Education no 2(16) 2019, Poznań 2019, pp. 163-181, Adam Mickiewicz University Press. ISSN 2300-0422. DOI 10.14746/kse.2019.16.11.

December 12, 2016 a group of eleven first-year students of history organized at the Institute of History of Nicolaus Copernicus University in Torun (Poland) participated in the field work carried out in the church Roman Catholic parish of St. Jacob the Apostle in Torun. During a visit in the temple the students performed an exercised to draw their attention: generally to the role of the imagination in the practice of the historian's research and training his own imagination in whole live. First, the authoress described a process of the exercise. Then she briefly pointed to the literature on the role of the imagination. Later she discussed the work that have arisen in the result of the exercise. Next she characterized the thoughts and impressions of students. She also outlined the importance of this exercise in a broader context. At the end she summed up the whole article.
\end{abstract}

On 12 December 2016, a group of five female students and six male students of the first year of bachelor-degree studies in history being held at the Institute of History and Archiving of the Nicolaus Copernicus University in Torun participated in

\footnotetext{
* ORCID https://orcid.org/0000-0002-2823-8550.
} 
field classes conducted under my supervision. The classes were held in the Roman Catholic parish church of St. James the Apostle in Torun. The meeting was a part of the curriculum of the subject called Introduction to History, co-ordinated by Prof. Kazimierz Maliszewski, PhD. The students participating in the meeting (persons aged between 19 and 21) were supposed to become familiar with elementary data concerning the history and valuable objects of the aforementioned church. ${ }^{1}$ During their visit to the temple, the participants of the classes performed an exercise aimed at drawing their attention to the role of imagination in the historian's research practice and developing their own imagination. I asked the students to take a look at the interior and exterior part of the temple and then try to draw the whole church or its fragment in the historical period or moment chosen by themselves. I suggested that they include not only the place, but also people in their drawings. Because of the various levels of their drawing skills, students were also asked to make a short description in order to specify which historical period they had chosen and what they had wanted to present in the drawings that they had made. It was important that students were not supposed to learn what was their task in the temple before coming to the church. If they had known this, they could have intentionally prepared themselves for this, consulted others or performed some part of it.

By way of introduction, it is necessary to mention that the role of imagination (including historical imagination) - in human life ${ }^{2}$ and specifically - is noticed and recognised ${ }^{3}$ in the practice of science. ${ }^{4}$ One of the examples of its use is the historian's professional experience (Hajduk, 2014: 11-26; Woźniak, 2013; 2010). In their research findings combining the biological perspective with the humanistic perspective, Piotr Przybysz and Piotr Markiewicz created a model of imagination encompassing the three elements: 1) quasi-imagination; 2) proto-imagination: 3 ) proper imagination. The first one generates a mental image of something that does not exist. The second one fulfils the same function; in addition, it allows us to detect the ambiguity of the equivocal stimulus. The last

${ }^{1}$ About the history of the Church of St. James in Toruń, vide: Kluczwajd, 2010; 2009; Krantz-Domasłowska, Domasłowski, 2001; Brochwicz, 1988; Sudziński, 1988.

${ }^{2}$ For examples of works emphasising the role of imagination in selected fields and at various stages of life, see: Jarczewska-Gerc, 2015; Kania, 2014; Kornhauser, Zając, 2012; Kowalski, 2011; Sztuka, 2010; 2001; Dyduch, 2007; Sajdera, 2003.

${ }^{3}$ About the role of imagination in research, vide: Nowak, 2013; Kamińska, 2003; Podrez, Czyż, 2002; Krawczyńska, 1999; Beveridge, 1960; Chojnacki, 1928.

${ }^{4}$ For more about the interpretation of the role of imagination over the centuries, see: Woźniak, 2013; Wróbel, 2008; Starobinski, 1972. 
one combines the features of the first two elements and then expands them. It leads to the creation of a visual image and enables its transformation and the free use of elements of its composition. According to P. Przybysz and P. Markiewicz, the described process is based on the creative advanced transformation of visual stimuli through the engagement of visual sensory data, the attention module, memory modules and high-level decision processes. And the whole process occurs due to illusory, magnified, relational and empathising stimuli (Przybysz, 2007: 136-139).

The development of imagination means the enlargement of the skill of its use and constitutes the goal of various exercises being practised within the scope of personal development. ${ }^{5}$ Therefore, the aim of this article is to present the results of work of students participating in the completed exercise and to discuss the importance of the completed task. At the beginning of the article, I will present short characteristics of created drawings and commentaries to them. Then I will present the impressions and reflections that the aforementioned exercise created among students. In the further part, I will refer to the meaning of this exercise in broader contexts and environments, i.e., those related to first-year students of history at Nicolaus Copernicus University. The interdisciplinary perspective will play a special role here, which will be explained more broadly below.

\section{Drawings showing significant processes and changes}

The drawings made by the students can be divided into three groups in respect of their content and meaning. The first group consists of works whose form resembles a photograph taken at the selected historical moment. The female student no. 1 made a picture that presents the local population gathered outside the church, near the door of the Torun temple of St. James the Apostle, in order to find shelter from mass deportations and murders of Polish intellectuals in the autumn of $1939 .{ }^{6}$ A majority of presented persons are women with children (one child holds a mascot in its hands). ${ }^{7}$

\footnotetext{
${ }^{5}$ For a description of specific exercises, see: Modrak, 2016; [B.A.], Tunel. Znaczenie ludzkości... 2012.

${ }^{6}$ To learn more about events presented in the drawing of the female student no. 1, see: Grochowina, 2009; Biskup, 2006; Jaszowski, 1971.

${ }^{7}$ Drawing and commentary by the female student no. 1 .
} 
Another work referring to World War II was prepared by the female student no. 2, who presented a meeting of people in the aforementioned church led by a presbyter on the occasion of the regaining of independence in 1945. It is a scene taking place inside the temple. Many persons holding red-and-white flags take part in it. The scene is shown from the perspective of the altar retable. It is important that the church layout (particularly the presbytery) was drawn from a modern perspective, not in a manner used before the Second Vatican Council. In the middle, we can see an altar table removed from the retable and on its left side we can see a pulpit. The speaking priest (maybe a bishop) is standing with his face towards the people. The student admitted that this type of perspective resulted from the fact that she had given in to the visual stimuli of the temple in which she was staying, forgetting about the appearance of the presbytery in 1945, i.e., before the Second Vatican Council. ${ }^{8}$

The drawing by the female student no. 3 is considerably different from the aforementioned ones. It shows the building of the entire church of St. James in Torun seen on the outside from a certain distance. It also shows the trees growing around the church and the cemetery wall. In addition, it presents a few nuns heading for the main entrance of the temple. The sisters are wearing habits and veils, holding their hands together in a gesture of prayer, and crosses hang from their necks. In the description to her sketch, the female student no. 3 informed that she had included the sight of the temple in her work after 1345, when Cistercian nuns began taking care of the church. ${ }^{9}$ This sketch was prepared with the help of a drawing contained in one of the books being a work on the history of the temple. The student admitted having used data from the book, but, following her imagination, she brought some changes to her sketch. ${ }^{10}$

The work of the male student no. 1, presenting scaffoldings and a ladder placed inside the church, also refers to the Middle Ages. Over the scaffolding, there is a sketch of the fresco being created. In the description, the student stated that he had shown works being conducted in the second half of the $14^{\text {th }}$ century, the aim of which was to create a painting presenting Christ and Our Lady in the scene of the Coronation of the Blessed Virgin Mary. ${ }^{11}$

${ }^{8}$ Drawing and commentary by the female student no. 2.

9 To learn more about the service of nuns in the Church of St. James in Torun, see: Rozynkowski, 2015: 9-19; Wierzbicka, 2013: 7-35; Słyszewska, Nadolny, Wałkowski, 2010.

${ }^{10}$ Drawing and commentary by the female student no. 3.

${ }^{11}$ Drawing and commentary by the male student no. 1; see: Wierzbicka, 2013. 


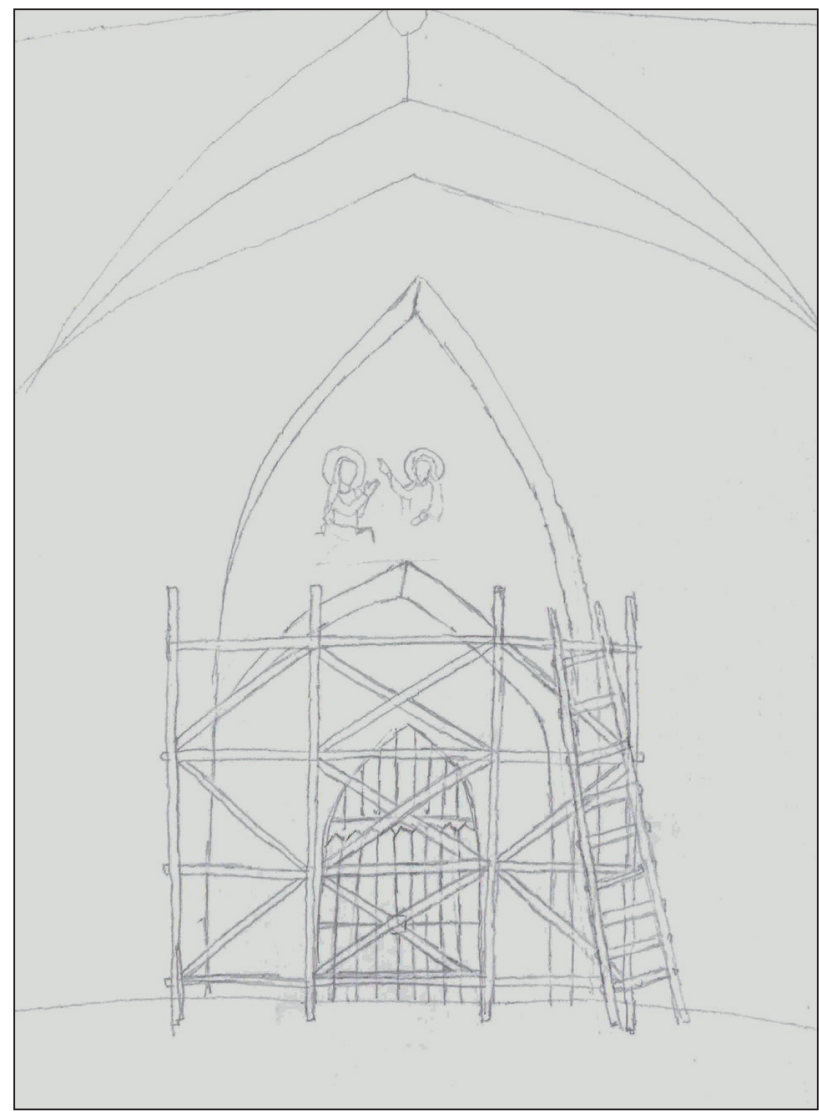

Fig. 1. Drawing by the male student no. 1

Just like the drawing by the female student no. 3 , the drawing by the male student no. 2 shows the church seen from the outside. People are moving into it, being welcomed in front of the entrance by a nun and a priest (their status is expressed by clothes, i.e., a habit and a veil in the nun's case and a cassock and a collar in the priest's case). The student attached to his drawing a short description of the history of the temple, explaining the reason for the inclusion of individual persons' images in the sketch. He wrote that the church was built in the $14^{\text {th }}-15^{\text {th }}$ century. It was initially managed by Cistercian nuns, then by Benedictine nuns, the diocesan clergy and again Benedictine nuns until the $19^{\text {th }}$ century. In the $19^{\text {th }}$ century, the church changed its status and became a parish temple. In view of this, the sketch presents the day of creation of the parish and the entrance of 'lucky parishioners going into their parish. ${ }^{12}$

12 Drawing and commentary by the male student no. 2; see: Kluczwajd, 2009. 
Works contained in this group have their own emotional weight. The gestures of persons (hugging each other, knocking on the church door) and their mimics (showing tears or a smile) express fear, hesitancy, pain or joy. Particularly the scene drawn by the male student no. 1 is full of anxiety and dynamics. The image presenting the creation of the fresco seems to be the least emotional. It is significant that the author of the drawing did not contain any creator of the painting in the sketch. Nevertheless, the presentation of the unfinished fresco and standing scaffoldings shows the processuality of creation of the work that was prepared by authors in question. All works presented in this group along with commentaries show processes and changes important for the ecclesial community, which are sometimes entwined in the global history (such as the outbreak and conclusion of World War II). In this group, history is usually perceived personalistically and subjectively-anthropocentrically, i.e., through the prism of the history of people, its activity and context of life. ${ }^{13}$

\section{Drawings of selected works of art}

The second group of drawings includes those that present mainly a selected work of art located in the Church of St. James the Apostle in Torun. This group, just like the first one, consisted of five works. The first one refers to the crucifix The tree of life [Drzewo $\dot{z} y$ cia] from the $4^{\text {th }}$ quarter of the $14^{\text {th }}$ century and was created by the female student no. 4 . It is worth mentioning that the crucifix is one of the most important historic objects in Torun. In her sketch, the student contained mainly the image of a large cross and people praying at its foot. The student's description shortly deals with the theological meaning of this object. She wrote that it had been perceived 'as a cultural standard that symbolised the perpetual revival of nature. For Christians, the tree of the cross is the place where death became the beginning of life. ${ }^{14}$ The author also wrote that a copy of the work selected by her is placed in the main altar of the cathedral of the Immaculate Conception of the Blessed Virgin Mary in Moscow (see Waszak, 2013: 9-36).

${ }_{13}$ About personalistic history, confer: Grabski, 2003: 739; Braudel, 1971: 158; Bloch, 1962: 5052; Wrzosek, 1995: 80-81, 103; Labuda, 2010: 126.

${ }^{14}$ Drawing and commentary by the female student no. 4. 


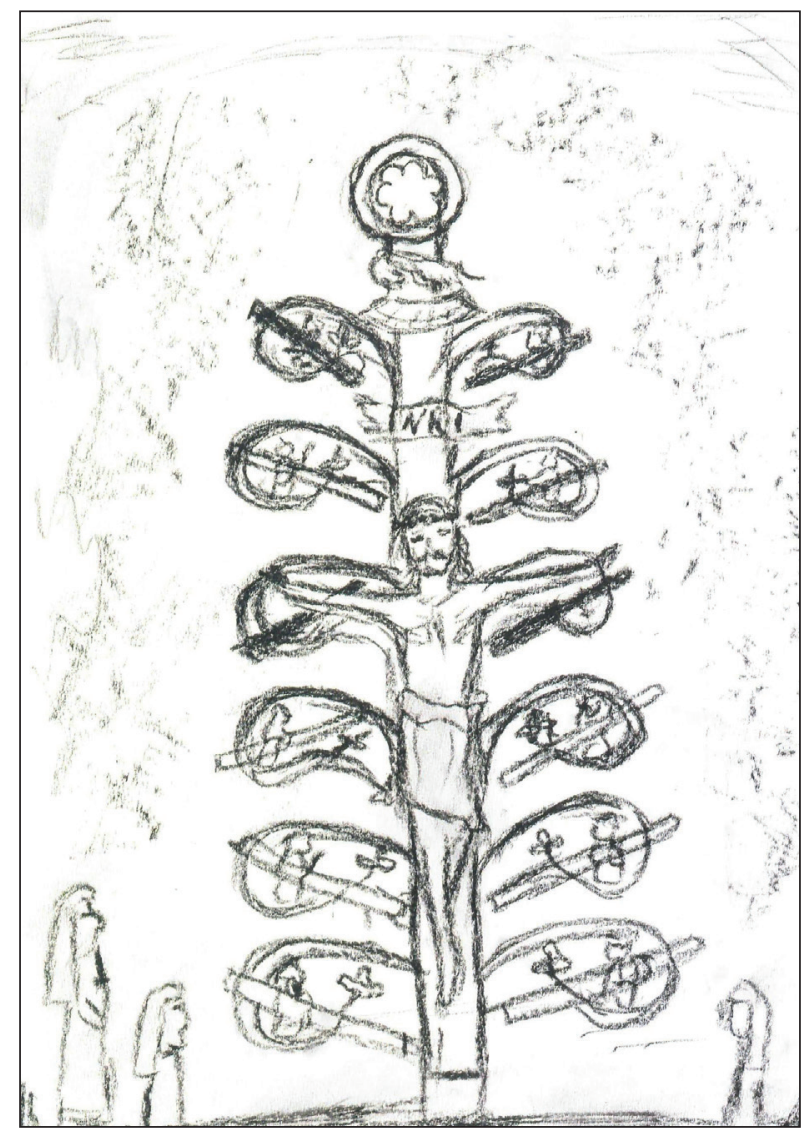

Fig. 2. Drawing by the female student no. 4

The work of art selected by the male student no. 3 also refers to the Middle Ages. It showed a painting with $14^{\text {th }}$-century images of St. Sebastian, St. Dorothy and St. Martin. The figures of saints are distinguished by their attributes contained in the sketch. This work is characterised by the fact that it presents not only an abstracted work of art (as in other drawings from this group). It also shows selected elements of church architecture (support arches) during the construction of the church in the $14^{\text {th }}-15^{\text {th }}$ century. On the side of the sketch, the author contained also images of people located in the temple (presumably pilgrims). ${ }^{15}$

Another participant of the classes, the male student no. 4 presented a $17^{\text {th }}$-century figure of Our Lady holding Christ's Cross and roses. In his commentary to the sketch, the author contained information about the history of this work and

${ }^{15}$ Drawing and commentary by the male student no. 3; see: Wierzbicka, 2013. 
its meaning placed in the context of the cult of the Blessed Virgin Mary in Polish lands in modern times. ${ }^{16}$

The next work by the male student no. 5 refers to a painting of the Heart of Jesus. It contains two drawings: 1 ) a contemporary drawing; 2 ) a $17^{\text {th }}$-century drawing. In the commentary, the student created a description of alternative history, where - making use of his imagination - he noted that a painting of Our Lady with an equally strongly emphasised perception of the heart may have been previously located in the place of the painting selected by him. This work may have been stolen by Swedish troops during the Swedish Deluge or by other occupant (e.g., German troops during World War II). The student found that the change of the painting may have also resulted from the will of God's people and a concrete individual. The author of the opinion concluded that it is possible to create various hypotheses - less or more credible ones - without background information. ${ }^{17}$

The last work belonging to the group of drawings that present primarily a selected work of art from the Church of St. James the Apostle in Torun is clearly different from others. The female student no. 5 in the sketch contains the scene of consecration of a Baroque organ in the aforementioned temple in 1611. This perspective stands out among others in respect of the multidimensionality of its message. Firstly, it presents the organ placed inside the church (the back wall and fragments of side walls of the building can be seen). Secondly, the author framed the perspective as much as possible in the case of photographs. The spectator's attention is drawn by a large instrument, and at the bottom of the perspective there is a minimal view of tops of worshippers' heads, above which the procession cross and the smoke of the incense rise. As the student decided, the procession of worshippers is barely visible, because sunrays falling from the window onto the organa symbol of blessing of God Himself - are more important. ${ }^{18}$ In the top left corner of the sketch, you can see the window and the sunrays falling through it. With regard to this, the drawing shows not only an image of the event from the past (i.e., consecration of the organ) and the theological and miraculous sense of this act expressed by sunrays as a natural element. Therefore, the female student's sketch has an artistic meaning that is much more advanced than in the case of other works.

${ }^{16}$ Drawing and commentary by the male student no. 4: about the meaning of the cult of the Blessed Virgin Mary and her images in Polish lands in modern times, vide: Witkowska, 2013; Kusztelski, Kurzawa, 2012; Szwarocka, 2010.

17 Drawing and commentary by the male student no. 5; about the combination of fictional and non-fictional narration in the practice of history, vide: Struski, 2015; Zajas, 2011; Chmielewska, 2011: 48-49.

${ }^{18}$ Drawing and commentary by the female student no. 5 . 


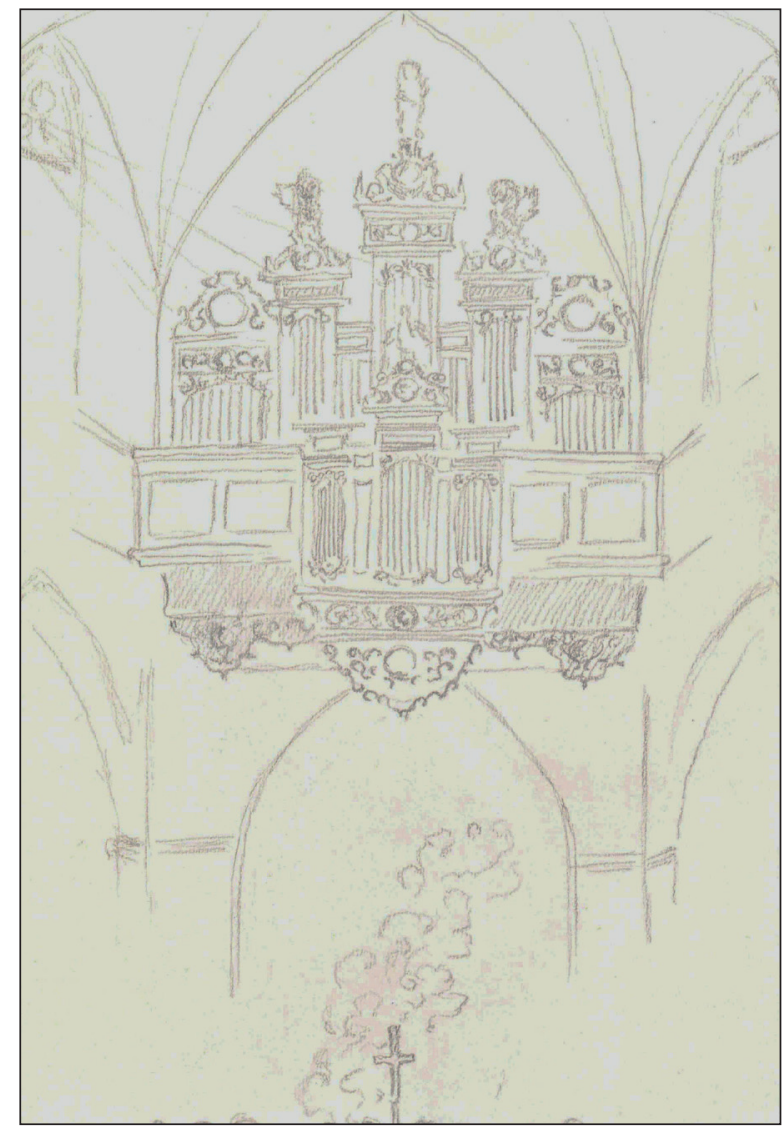

Fig. 3. Drawing by the female student no. 5

We can guess that, upon application of paint onto the sketch, the drawing could gain a chiaroscuro element that would emphasise even more strongly the contents that the author of the work wanted to communicate to the recipient. ${ }^{19}$

The drawings and commentaries to them presented in this group serve as a proof of existence of historical imagination focusing on objects and their history. It is, therefore, a subjective and material interpretation of history. ${ }^{20}$ It is worth noticing that male students did not choose any vessel, clothes or piece of liturgical

${ }^{19}$ Drawing and commentary by the female student no. 5 .

${ }^{20} \mathrm{~J}$. Michalski combines the shift from the objective-material narration to the subjective-anthropocentric narration with the change of language that was applied during the sessions of the Second Vatican Council. Authors of historiographic studies draw our attention to changes in the historical narration that occurred as a result of the functioning of the Annales School (particularly thanks to L. Febvre and M. Bloch) and subsequently F. Braudel; Grabski, 2003: 739; Michalski, 2004: 80. 
furniture (e.g., a chalice or a confessional); instead, they focused on other historic objects of art (a figure, a painting, a cross, an organ, architectural elements). ${ }^{21}$ We must also note that commentaries to drawings include the data about the history and meaning of selected objects that the students had learned earlier. In one case (i.e., the work of the male student no. 5), the entire description of the work is a result of imagination, so this text constitutes a hypothesis not based on historical sources and works.

\section{Commentary without a drawing}

Apart from the ten drawings and commentaries to them discussed above, there was also one written opinion without a sketch. The male student no. 6 chose and then discussed a $16^{\text {th }}$-century wall painting depicting Christ the King, Mary the Queen of Heaven and Earth and angels placed on their sides. From the beginning of the task, the male student no. 6 focused only on the preparation of the note. He described the location and content of the selected painting and its meaning for a Torun Catholic townsman who faced the ongoing Reformation. The student imagined that the Roman-Catholic townsman had seen the painting in question when leaving the church. In reaction to its content, he gained a sense of security, freedom from heresy and the conviction of his own salvation on the Last Judgement. ${ }^{22}$

The student subsequently confirmed that he deliberately and consciously did not make the ordered drawing. He also admitted that, when imagining the scene described above, he had not built an image in his mind, but he had constructed the verbal message directly. In view of this, we must notice that imagination was used in this case. The consequences of its use became immediately visible in words, not in pictures.

\section{Impressions and reflections of students on the experienced exercise}

A summary of the exercise held during field classes took place two days after the meeting in the church, i.e., on 14 December 2016 during Introduction to History classes in the university's teaching room. When I asked students about the impres-

\footnotetext{
${ }^{21}$ Confer: Radomski, 2001.

${ }^{22}$ Commentary by the male student no. 6; about the history of Torun in the age of Reformation and Counter-Reformation, vide: Biskup, 1994; 1996.
} 
sions and emotions that had accompanied them during the exercise, they noticed that the stay in the temple had provided them with a much more interesting form of university classes than usually in teaching rooms. The detailed data concerning their perception of the said exercise were included in an anonymous questionnaire that they filled on 14 December.

The questionnaire contained eight questions:

1) Do you think that a historian needs imagination?

2) Do you consider exercises in historical imagination generally useful for a historian?;

3) Do you think that the method of exercising historical imagination experienced by you was appropriate?;

4) What impressions, emotions and reflections accompanied you during and shortly after the completion of the exercise?;

5) Do you intend to repeat such exercise in the future?;

6) Would you recommend the same exercise to anybody else? If yes, to whom?;

7) Have you performed any similar exercise before (i.e., before 12 December 2016)? If yes, when, where and what was its purpose?

8) Do you study, or have you studied any other field than history? If yes, which? ${ }^{23}$

The students were supposed to provide answers in accordance with their subjective feelings and beliefs and to justify their opinions apart from answering 'yes' or 'no'. All eleven respondents answered the first and second question positively. They thought that a professional historian should deal with facts and their meaning and, therefore, imagination is a necessary working tool for him. It also allows him to move metaphorically in time to the epoch under analysis, to imagine events and contexts, and to understand reasons, intentions, affections and motivations of historical figures. Therefore, it is generally necessary to exercise one's historical imagination in order to develop one's own empathy, intellectual skills and other spheres necessary in everyday life.

As regards the answer to the third question in the questionnaire, everybody except one person believed that the method of exercising historical imagination that they have experienced was appropriate. One student admitted that, because of the lack of artistic talent, he focused on the form of the drawing rather than the actual goal: making use of imagination. For this reason, the respondent did not consider repeating this exercise in the future, but he would recommend it to per-

\footnotetext{
${ }^{23}$ A. Laddach, 'A questionnaire conducted after field classes and an exercise in historical imagination,' Toruń, 14 December 2016.
} 
sons with artistic skills and historical interests connected with the selected epoch or period.

When answering the fourth question, the students wrote that the exercise had produced concrete emotions in them. The respondents mentioned: 1) curiosity, mysteriousness, reflections, a feeling of the climate of the past; 2) the conviction about participation in a non-standard exercise, allowing the respondent to be present in the given period for a longer moment; 3 ) a feeling of the continuity of history and the heritage of the past centuries, the conviction about the inefficiency of the current centuries towards the monument of the past; 4) a feeling of arousal of one's imagination, initially a bit of a shock as a reaction to the received command, followed by positive emotions during its fulfilment; 5) satisfaction, curiosity, interest, the will to repeat a similar exercise; 6) amazement; 7) concern about the form and concentration on the lack of artistic talent preventing the respondent from focusing on the role of imagination; 8) positive emotions, impressions and reflections; 9) the conviction about participation in a fantastic experience, resulting, e.g., from staying in a hardly accessible and favourite place (a church in the morning, with the absence of liturgical ceremonies and a small number of co-present persons), an experience of long-term reflections resulting from participation in the exercise; 10) curiosity, interest in the building, positive experiences about the method of exercises and the assigned task; 11) a feeling of participation in the past moment and the historical event taking place in the Church of St. James in Torun that the respondent had chosen.

Among answers to the fifth question (Do you intend to repeat the proposed exercise in the future?), there was one negative answer; the author of the latter found that he does not rule out repeating the exercise, but he would not recommend his own experience to others. Other respondents admitted that they would repeat the task in the future, because it helps them develop their imagination. In one case, the respondent noted that the said exercise enlarged the borders of the mind. In other opinions, the respondents wrote that the development of imagination through the proposed method helps to learn much about the given place, to sightsee it, and to feel the atmosphere of the building/facility. As noticed above, everybody except one student would recommend the performance of the exercise to other persons.

In response to the sixth question (Would you recommend the same exercise to anybody else? If yes, to whom?), the respondents indicated several groups of persons to whom they would propose the exercise experienced by themselves. Altogether, they mentioned: all people (without determining their specific features), students of secondary schools with a humanistic profile, students and enthusiasts of history, students of philologies and other humanistic studies, future writers and 
poets, persons with artistic skills, professional historians, history teachers, persons conducting classes in the given place (implicitly understood as guides).

The answers given in the questionnaire indicated that almost all students had participated in the exercise proposed to them for the first time. The three female students constituted an exception (accounting for $27 \%$ of all respondents). One of them wrote that she had worked with other people among the monuments of Gniew (the castle, churches on the market square) in the first class of secondary school. She did not specify the details of that work. We should guess from the context that her task had been to prepare a drawing of the place. We do not know, however, whether these were classes in an artistic, monument science, historical or other field. The second student informed that she had performed a similar exercise in the ruins of the castle in Bobrowniki. The aim of the task being performed by her was to enlarge her knowledge about the place in which she was staying. The third respondent noted that she had regularly attended military facilities (e.g., forts) in order to get a better understanding of history and the tactics of individual actions.

Because of the alleged impact of other research paradigms in which respondents could potentially move around in intellectual terms, they were asked about taking up other fields of study. It turned out that, apart from history, the four persons studied or are studying also: 1) sociology and a field in officer studies; 2) information management and bibliology (it is one field of study); 3) law; 4) military studies. The student of sociology and officer studies highlighted the unnecessary visualisation of the past and the key role of verbalisation in the work of a historian who is preparing a description rather than a painting with an image of past events. He informed in the questionnaire that he focused on the feeling of continuity of centuries and the greatness of the past history surpassing modern times. He had never participated in a similar task before and he would not recommend its performance to anyone. At the same time, he stated that a historian would need imagination for making a synthesis of history and building a narrative logical sequence. The student of information management and bibliology gave a positive answer to questions 1-3, 5 and 8 . He wrote in the questionnaire that he had never performed a similar exercise before. In his answers, he manifests a sense of participation in the exercise as something new, innovative and significant for the development of his mind and an interesting proposal for other persons. The student of law gave a positive answer to questions 1-2, 6 and 8 . Because of the conviction about his own lack of drawing talent, he evaluated negatively the proposed method of exercise in the development of historical imagination. The student of military studies remarked that physical presence in military facilities helps her understand the 
events that took place there and to feel the atmosphere of the building/facility. She gave a positive answer to questions $1-3,5$ and 8 . She recommended the performance of the said task to all persons dealing with humanistic sciences.

\section{Broader uses of the exercise in question}

Both in the students' opinion and in my view, the proposed exercise developing imagination (particularly historical imagination) has a chance to succeed not only among first-year students of history at Nicolaus Copernicus University, but in persons representing other environments. This text is, therefore, both a description of the case of performing an exercise and a proposal for other persons conducting classes among students of history. Maybe an attempt should be made to perform a similar exercise among secondary school students within the scope of various humanistic lessons: history, visual arts, cultural knowledge, Polish, religion. The relevant decision rests with individual teachers who know the intellectual and educational capabilities of their pupils. ${ }^{24}$ It is necessary to agree with the respondents who remarked that the development of historical imagination is important also for students of various field of study, artists and persons working as teachers, guides or narrators. The interdisciplinary character of the exercise manifests itself here. It highlights the need to develop the imagination of representatives of various scientific fields and, more broadly, diverse environments. At the same time, the choice of a location for performing the exercise plays an important role in this context. It can be both a building (or another text of culture) and a natural environment (e.g., a meadow, a glade, a forest, a river) that was an arena and a witness of historical events. It is, however, necessary to mention that, during the choice of the place, the participants of the exercise are introduced to a concrete space determining the subject area of the interpretation. For example, students staying in the church referred to their knowledge and ideas of a sacred place to a varying extent. They referred to issues in such fields as theology, art history, art knowledge, cultural history, or sociology. If they were invited to participate in the said exercise, e.g., in the ruins of the former hospital, they should refer to knowledge about medicine and its history, the history of hygiene, sociology or building industry.

${ }^{24}$ About the introduction of the pupil's interactions with the cultural-historical environment during school lessons in history, confer: Dworakowski, 2004: 346-351; Bednarzak-Libera, 2004: 352-361. 
Being guided by knowledge about the role of imagination in human life, which is reflected by the literature of the subject mentioned in the introduction to this article, we must admit that the proposed exercise could be interesting for each human being. There is a chance to develop it in an interdisciplinary approach. The limitations connected with the imperfect painting talent of individual persons can cause some difficulty in the performance of the task. We must remember, however, that the aim of the exercise is not to create a drawing in itself, but to make use of imagination in the sketch creation process. Therefore, the exercise should be carried out in an atmosphere of fun and some kind of experiment. ${ }^{25}$ It is necessary to lay emphasis not on the objective result of work (i.e., the drawing and the commentary to it), but on the subjective and processual interpretation of the experience that happens mainly in the minds of participants of the exercise. The ultimate aim is, therefore, to stress the formation of their sensitivity, empathy, curiosity, inquisitiveness, historical awareness and, obviously, imagination. Within the scope of goals interpreted in such a way, the said exercise can be interpreted as one of the methods of practising applied history. ${ }^{26}$ Following the answer given by one of the female respondents, participation in the exercise is also an opportunity to experience a metaphorical journey in time allowing participants to observe a selected segment of the past and to return to the present day. According to studies carried out by Barbara Szacka, it is one of the wishes verbalised by people of modern culture (Szacka, 2014: 173-185).

Drawings made by first-year students of history at Nicolaus Copernicus University, commentaries to them and opinions contained in the questionnaire draw our attention to another fact. Living in a pictorial culture, most persons agreed to the visualisation of the past by means of an image. One person prepared only a description. This situation shows that imagination works in many fields, not only in a visual field, as might initially seem and as P. Przybysz and P. Markiewicz suggested (Przybysz, Markiewicz, 2007: 111-149). Imagination (including historical one) works also in the field of verbalisation, hearing and the sense of touch without vision (which is proven by musical works and sculptures made by blind or visually impaired persons). Another important factor is knowledge in the given field, which makes it possible to create works. For example, writing a musical work on paper without checking the sound of each harmony and rhythmic value is possible, because the aforementioned harmonies and lengths of sound are determined by mathematical values. Thus, thanks to calculations, it is possible to identify

\footnotetext{
${ }^{25}$ About the role of experiment in practising history, vide: Wiślicz, 2014: 59-66.

${ }^{26}$ About applied history, vide: Traba, 2014: 143-164.
} 
sounds making up a key and an interval and their length in a bar. The presented example fits into a conception according to which knowledge without additional sensory stimuli can be a source of imagination. It is, however, necessary to note that the human being acquires this knowledge in the natural process by listening, seeing, touching, tasting and smelling. The role of senses in the development of the human being is indisputable.

\section{Summary}

This article deals with an exercise performed among first-year students of history at Nicolaus Copernicus University in the Roman Catholic parish church of St. James the Apostle in Torun. On the basis of completed drawings, commentaries to them and opinions provided in an anonymous questionnaire, we can say that the aim of the exercise was accomplished. The students realised the important role of imagination in human life, particularly in the historian's work. At the same time, they exercised their own historical imagination. The experiences noted down by respondents allow us to hope that they would repeat the said exercise (in the same or another place) and invite other persons to it.

As observed in the submitted article, the described example is a proposal to enrich classes and to stimulate the activity of university students and secondary school students. It can also be conducted as a part of living history lessons, the popularisation of history and cultural heritage, and the practising of self-development. Of course, the presented method of activation remains imperfect. Nevertheless, favourable opinions about it allow us to presume that a relatively simple task can bring profound methodological reflections to participants.

\section{List of sources}

Drawing and commentary by the female student no. 1 .

Drawing and commentary by the female student no. 2 .

Drawing and commentary by the female student no. 3 .

Drawing and commentary by the female student no. 4 .

Drawing and commentary by the female student no. 5 .

Drawing and commentary by the male student no. 1 .

Drawing and commentary by the male student no. 2 .

Drawing and commentary by the male student no. 3 . 
Drawing and commentary by the male student no. 4 .

Drawing and commentary by the male student no. 5 .

Commentary by the male student no. 6 .

Laddach A., 'A questionnaire conducted after field classes and an exercise in historical imagination,' Toruń, 14 December 2016

\section{Bibliography}

[B.A.], Tunel. Znaczenie ludzkości dla przyszłości. Ankieta, Opole 2012.

Beveridge W.I. (1960), Sztuka badań naukowych, trans. L. Żebrowski, Warszawa.

Biskup M. (1994), Historia Torunia, vol. 2, is. 2: W czasach renesansu, reformacji i wczesnego baroku (1548-1660), Toruń.

Biskup M. (ed.) (1996), Historia Torunia, vol. 2, is. 3: Między barokiem i oświeceniem (1660-1793), Toruń.

Biskup M. (ed.) (2006), Historia Torunia, vol. 3, is. 2: W czasach Polski Odrodzonej i okupacji niemieckiej (1920-1945), Toruń.

Bloch M. (1962), Pochwała historii, czyli o zawodzie historyka, trans. W. Jedlicka, Warszawa.

Braudel F. (1971), Historia i trwanie, trans. B. Geremek, Warszawa.

Brochwicz Z. (1988), Materiały i techniki malarskie średniowiecznych malowideł ściennych w kościele św. Jakuba $w$ Toruniu, Toruń.

Chmielewska J. (2011), Non-fiction, czyli historia pewnej umowy, Nowe Książki no. 10, pp. 48-49.

Chojnacki P. (1928), Pojęcia i wyobrażenia w świecie psychologii i epistemologii, Kielce.

Domańska E., Stobiecki R., Wiślicz T. (eds.), (2014), Historia - dziś. Teoretyczne problemy wiedzy o przeszłości, Kraków.

Dyduch B. (2007), Między słowem a obrazem. Dylematy wspótczesnej polonistyki, Kraków.

Grabski A.F. (2003), Dzieje historiografi, Poznań.

Grochowina S. (2009), Barbarka. Miejsce niemieckich egzekucji Polaków z Torunia i okolic (październik-grudzień 1939), Toruń

Hajduk J. (2014), Wyobraźnia, przedstawienie, narracja. O literackości pisarstwa historycznego, Sensus Historiae no. 1, pp. 11-26.

Jarczewska-Gerc E. (2015), Rola wyobrażeń w osiaganiu celów. Symulacje mentalne, Warszawa.

Jaszowski T. (1971), Niemy świadek. Zbrodnie hitlerowskie w toruńskim Forcie VII $i$ w lesie Barbarka, Bydgoszcz.

Kamińska A. (2003), Gaston Bachelard: rzeczywistość wyobraźni, Lublin/Bensheim.

Kania M.M. (2014), Żywioły wyobraźni. O wyobrażaniu i przeobrażaniu, Kraków.

Kluczwajd K. (2009), „Kościót św. Jakuba Apostoła w Toruniu. 700 lat świątyni (1309-2009), Torun.

Kluczwajd K. (red.) (2010), Dzieje i skarby kościoła Świętojakubskiego w Toruniu. Materiały z IV Sesji Naukowej Toruńskiego Oddziału SHS, Toruń.

Kornhauser J., Zając D. (eds.), (2012), Horyzonty wyobraźni. Fantazja i fantastyczność we współczesnej kulturze, Kraków.

Kowalski P. (2011), Mit, prawda, imaginacja, Wrocław.

Krantz-Domasłowska L., Domasłowski J. (2001), Kościół świętego Jakuba w Toruniu, Toruń. 
Krawczyńska T. (1999), Nauka i wyobraźnia (review: M. Rees, Przed poczatkiem. Nasz Wszechświat i inne wszechświaty, Warszawa 1999), Zagadnienia Filozoficzne w Nauce no. 1, pp. 124-128.

Kusztelski A., Kurzawa Z. (2012), Kult loretański w sztuce Rzeczypospolitej (koniec XVI - początek XIX w.), Poznań.

Labuda G., „Rozwój metod dziejopisarskich od starożytności do współczesności”, vol. II., „Wiek XX”, Poznań 2010.

Michalski J. (2004), Obecność kultury w katechezie, Keryks no. 3, pp. 79-96.

Modrak M. (2016), Program ochrony pamięci, vol. 3: Wyobraźnia - uskrzydlanie fantazji, Kraków.

Nowak A.W. (2013), Wyobraźnia ontologiczna - przekraczanie metodologicznego solipsyzmu a obietnica badań interdyscyplinarnych, Avant no. 2, pp. 338-362.

Podrez E., Czyż A. (2002), Wyobraźnia jako jaźń twórcza. Studia z etyki, literatury i sztuki, Warszawa. Przybysz P., Markiewicz P. (2007), Neuroestetyczne aspekty komunikacji wizualnej i wyobraźni, [in:] P. Francuz (ed.), Obrazy w umyśle. Studia nad percepcją i wyobraźnią, Warszawa, pp. 111-148.

Radomski A. (2001), Sztuka jako źródło do badania historii. Czy historiografia jest sztuką? (na przykładzie literatury), Historia i Kultura no. 1, http://www.kulturaihistoria.umcs.lublin.pl/archives/37, accessed: 17.12.2016.

Roszak S., Strzelecka M., Ziółkowski M. (eds.) (2004), Toruńskie spotkania dydaktyczne. Tradycja i mity w edukacji historycznej $w$ dobie reformy, Toruń.

Rozynkowski W. (2015), Święci jako patronowie obiektów sakralnych w państwie zakonnym w Prusach: na przykładzie miast, Studia Elbląskie no. 1, pp. 9-19.

Sajdera J. (2003), Dziecięce wyobrażenia w kontekście rówieśniczych relacji, Kraków.

Słyszewska A., Nadolny A., Wałkowski A. (2010), Biblioteki i skryptoria cysterskie na Pomorzu, Pelplin.

Starobinski J. (1972), Wskazówki do historii pojęcia wyobraźni, Pamiętnik Literacki no. 4, pp. 217-232.

Struski J. (2015), Możliwość wykorzystania historii alternatywnej w procesie nauczania i uczenia się historii, Strzelce Opolskie, http://pdf.helion.pl/s_2o00/s_2o00.pdf, accessed: 7.02.2017.

Sudziński R. (1988), Toruń: portret miasta, Toruń.

Szacka B. (2014), Stosunek do przeszłości i jej przeżywanie w ponowoczesnym świecie popkultury, [in:] E. Domańska, R. Stobiecki, T. Wiślicz (eds.), Historia - dziś. Teoretyczne problemy wiedzy o przeszłości, Kraków, pp. 173-185.

Sztuka K. (2001), Psychologia dla artystów. Widzenie, słyszenie, przetwarzanie, wyrażanie, Częstochowa.

Sztuka K. (2010), Wyobraźnia a rozwój duchowy, Kraków.

Szwarocka K.W. (2010), Sarmacka bogini. Kult maryjny w Polsce doby baroku, Toruń.

Traba R. (2014), Historia stosowana jako subdyscyplina akademicka. Konteksty i propozycje, [in:] E. Domańska, R. Stobiecki, T. Wiślicz (eds.), Historia - dziś. Teoretyczne problemy wiedzy o przeszłości, Kraków, pp. 143-164.

Waszak P. (2013), Krucyfiks na Drzewie Życia z dominikańskiego kościoła św. Mikołaja w Toruniu nowe spojrzenie, Sztuka i Kultura no. 1, pp. 9-36.

Wierzbicka M. (2013), Geneza i pierwsza faza budowy kościoła św. Jakuba w Toruniu w pierwszej połowie XIV wieku, Rocznik Toruński no 1, pp. 7-35.

Witkowska A. (2013), Ku ozdobie i obronie Rzeczypospolitej. Maryjne miejsca święte w drukach staropolskich, Lublin. 
Woźniak M. (2010), Przeszłość jako przedmiot konstrukcji. O roli wyobraźni w badaniach historycznych, Lublin.

Woźniak M. (2013), Wyobraźnia (historyczna) i jej rola w procesie badania przeszłości, Pamięć i Sprawiedliwość no. 2, pp. 41-53.

Wróbel Sz. (ed.) (2008), Światłocienie wyobraźni, Poznań-Kalisz.

Wrzosek W. (1995), Historia - kultura - metafora. Powstanie nieklasycznej historiografii, Wrocław.

Zajas P. (2011), Jak świat prawdziwy stał się bajką. O literaturze niefikcjonalnej, Poznań. 
